Artigos de opinião

\title{
A mulher camponesa e suas lutas pelo direito à saúde
}

\section{The rural women and their struggle for the right to health}

\section{La mujer campesina y sus luchas por derecho a salud}

Pensar e construir uma política de saúde para os povos do campo, da floresta e das águas tem sido um desafio de vários anos. Em 2004, com a instituição do Grupo da Terra, foi iniciado o debate e a construção de cada passo da Política Nacional de Saúde Integral da População do Campo, Floresta e Águas (PNSIPCFA). Naquela ocasião, os Movimentos Sociais Populares foram convocados para dar sua contribuição, o que foi importante, pois nada mais justo do que ter como protagonista da política aqueles que vivem a realidade em questão.

A saúde pública está nas lutas do Movimento de Mulheres Camponesas (MMC). A defesa do Sistema Único de Saúde (SUS) público universal e de qualidade, com as políticas complementares, deve resultar na promoção da saúde das mulheres do campo e de suas famílias.

Se olharmos para a história, percebemos que o cuidado com a saúde tem sido uma das preocupações das mulheres: a observância do comportamento da natureza, seus ciclos e sua comparação com o corpo das mulheres, que estão presentes na relação das fases da lua com o calendário menstrual e também com a duração da gravidez. As experiências com as sementes, plantas medicinais, aromáticas e alimentícias propiciaram aprimoramento de seus conhecimentos.

A descoberta desses conhecimentos tornou as mulheres portadoras de poder e sabedoria. Essa sabedoria sempre foi socializada e aperfeiçoada pelas mulheres dentro das suas famílias, de geração em geração.

Esse poder, mais tarde, tornou-se ameaçador ao poder patriarcal, motivo pelo qual foi determinada a Caça às Bruxas, culminando com a matança de muitas mulheres e seus conhecimentos. Mesmo nesse período, as mulheres foram compartilhando o saber para mantê-lo vivo de modo que ainda hoje muita coisa permanece.

1 Integrante do Movimento de Mulheres Camponesas; representante no Grupo da Terra; participante do Grupo Gestor do Observatório da Política Nacional de Saúde Integral das Populações do Campo, da Floresta e das Águas. Contato: noemikrefta@yahoo.com.br 
A luta das mulheres se dá de muitas formas, uma delas é a conversa ao pé do fogão durante o preparo da comida, outra forma é nas visitas aos parentes, comadres, vizinhas, nas quais sempre tem uma receita, uma muda ou semente a ser trocada, ou ainda nos encontros organizados dos Movimentos.

Com essas diferentes formas de se proteger e de se organizar, as mulheres contribuíram e continuam contribuindo com o cuidado da saúde de suas famílias e da comunidade.

É importante entender que as mulheres camponesas e suas comunidades têm seu modo de vida e de organização. Assim sendo, têm até mesmo um linguajar próprio para se comunicar e falar da saúde, das doenças, enfim, dos problemas que as rodeiam. Compreender essa organização, esse jeito de vida é indispensável para poder trabalhar a saúde pública com essas populações.

As rezadeiras, as benzedeiras, as raizeiras estão quase sempre presentes na comunidade e são procuradas para dar sua orientação. Muitas vezes, só depois desse processo é buscado o acesso ao serviço de saúde pública.

Com a organização das mulheres em espaços próprios como, por exemplo, o Movimento de Mulheres Camponesas, amplia-se a luta pela construção de políticas públicas de saúde que reconheçam as particularidades dessas populações, cujas demandas sempre têm pautado a necessidade de um atendimento qualificado e humanizado, com um olhar diferenciado para o campo.

A construção e a aprovação da PNSIPCFA foram processos importantes para o Grupo da Terra, pois cada termo, cada conceito foi amplamente discutido até ser consensuado e escrito nos textos da PNSIPCFA. Podemos hoje dizer que escrevemos uma política com a nossa cara, mas que precisa agora ser entendida e implementada pelos gestores.

Para isso, temos de continuar a luta na divulgação, atuando nos espaços de participação popular trazendo para a pauta a PNSIPCFA.

Como Movimento Social e Popular, entendemos que não basta ter uma política no papel, se não tivermos recursos para garantir a luta pela sua efetivação lá nas bases onde a saúde deve acontecer na sua plenitude. Assim, continuaremos atuantes e vigilantes na nossa missão de "Fortalecer a luta em defesa da vida". Todos os dias! 